\title{
The prevalence of and factors associated with constipation in elderly residents of long stay institutions
}

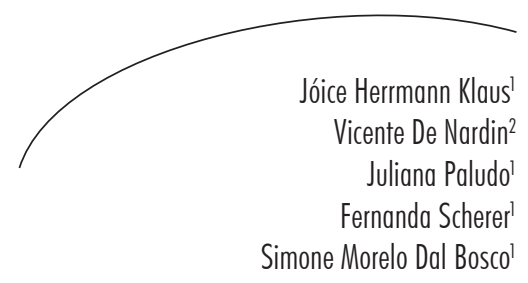

Abstract

Objective: Constipation is a frequent motility disorder and while a common complaint among the overall population, is particularly prevalent among the elderly. The increase of this population group is creating a growing demand for long term care institutions. The present study aims to investigate the prevalence of and factors associated with constipation in elderly residents of long stay care institutions. Method: The study involved 87 individuals. The data collected from each participant included gender, daily intake of water and fiber, physical activity, family history of constipation and nutritional status. The diagnosis of constipation was based on Roma III criteria. Statistical analysis was performed with the SPSS software program (version 18.0) with a level of significance of $5 \%(p \leq 0.05)$. The Student t, Mann-Whitney, Pearson's chi-square or Fischer's exact tests were employed. Results: The sample was predominantly female $(80.5 \%)$, with a mean age of 79.4( \pm 9.6$)$ years. A $42.52 \%$ prevalence of constipation was observed. Among affected individuals, the condition was more frequent among women (89.2\%), those aged over 80 years $(67.6 \%)$, those who did not engage in physical activity $(56.8 \%)$, those with below the recommended intake of water and fiber, those who had a family history of constipation, and those who were diagnosed with eutrophia (56.3\%). Among the factors analyzed, only age $(p=0.049)$ and low fiber intake $(p=0.019)$ were significantly linked to constipation. Conclusion: The results show that constipation is a multifactorial disease that is significantly related to age and low fiber intake.

\footnotetext{
Centro Universitário Univates, Centro de Ciências Biológicas e da Saúde, Departamento de Nutrição. Lajeado, RS, Brasil.

2 Universidade Federal de Ciências da Saúde de Porto Alegre, Departamento de Medicina. Porto Alegre, RS, Brasil.
}

Key words: Constipation. Elderly. Food Habits. Life Style. 


\section{INTRODUCTION}

The aging process includes specific characteristics which vary from person to person and culture to culture. ${ }^{1}$ The increase in the elderly population initially occurred in developed countries and has now spread to developing nations, such as Brazil, becoming a reality around the world. According to the Instituto Brasileiro de Geografia e Estatística ("the Brazilian Institute of Geography and Statistics") (IBGE), this rate of aging has resulted in changes to the age structure of the Brazilian population. In 2008, for each group of 100 children aged between 0 and 14 there were 24.7 elderly individuals aged 65 or older. In 2050, it is estimated that this scenario will change and for every 100 children aged between 0 and 14 years there will be 172.7 elderly people. ${ }^{2}$

Such accelerated populational aging has also had an effect on the number of institutionalized elderly people, who are considered vulnerable from a nutritional perspective due to the metabolic, physiological, anatomic and psychosocial disorders that come with age. ${ }^{3}$

At the same time as the aging process come changes in bodily functions which can be caused both by intrinsic factors related to advancing age, or by extrinsic factors such as diet, smoking, physical activity and body composition. ${ }^{4}$ These changes cause functional changes in the body of the elderly individual, as they occur in almost all parts of the body and can lead to constipation. ${ }^{5}$ This, in turn, is associated with factors such as advanced age, poor diet, inadequate fluid intake, physical inactivity, polypharmacy, and is related to a family history of constipation. ${ }^{6,7}$

Constipation is not a disease or a sign but a symptom, and as such, may originate from various intestinal and extraintestinal disorders. ${ }^{8}$ It is the most common digestive disorder among the general population, occurring predominantly among the female gender and affecting all age ranges, but most frequently affects individuals aged
65 or over, among whom prevalence can reach between $15 \%$ and $20 \%$, and can climb as high as $50 \%$ among institutionalized elderly persons. ${ }^{9,10}$ In the elderly population, constipation represents a serious health problem, ${ }^{11}$ and is responsible for around 2.5 million medical visits, and, indirectly, 92,000 hospitalizations in the United States each year, making it a more prevalent disease than a number of other common chronic illnesses such as hypertension, obesity and diabetes mellitus. ${ }^{12}$

Although constipation is a prevalent and serious condition of morbidity among the geriatric population, which may cause other diseases through the chronicity of its symptoms and the lack of adequate therapeutic guidance, it is still approached in a simplistic manner, which can have a negative effect on quality of life of individuals suffering from the illness. Given the above, this study aimed to investigate the prevalence of and factors associated with constipation in elderly residents of long stay care facilities.

\section{METHOD}

A cross-sectional study was undertaken. The sample consisted of elderly residents in seven long-stay public care facilities located in Vale do Taquari, which is located in the central region of Rio Grande do Sul, with a population composed mainly of German, Italian and Azorean ethnic groups, who enjoy an excellent quality of life and longevity. All the elderly individuals $(\mathrm{n}=231)$ were invited to participate in the survey, and of those, 87 agreed to take part and met the inclusion criteria, namely: (1) lucid individuals, according to the evaluation of the main researcher and nursing staff (2) residents of the participating institutions (3) do not use laxatives. The participants agreed to take part in the study by signing a Free and Informed Consent Form (FICF). The study was approved by the Ethics Research Committee of the Centro Universitário Univates, under registration no 161.374/2012. 
Data collection took place between March and June 2013, through a structured questionnaire that gathered data on age, gender, daily water intake, activity level (bedridden or light activity) and knowledge about the presence of family history of constipation. Information about daily fiber consumption was collected from the menu prepared by the nutritionist of each institution. A food registering tool was applied for three days in order to check food intake. The professional version of the Dietwin 2008 software program was used to analyze food consumption. The fiber intake of each of the three days was noted, before the average daily consumption was calculated. Fiber consumption was compared with the standard amount recommended by Dietary Reference Intakes (DRIs) ${ }^{13}$ which provides the Recommended Dietary Allowance (RDA) of individuals. In the absence of an RDA, Adequate Intake (AI) was used. Anthropometric data regarding the weight $(\mathrm{kg})$ and height $(\mathrm{m})$ of the participants was obtained, and the elderly individuals were weighed in the center of a Plenna ${ }^{\circledR}$, digital scale with a capacity of $150 \mathrm{~kg}$, while barefoot and wearing light clothing. Height measurement was performed using a tape with a total length of 2 $\mathrm{m}$. The elderly person was measured barefoot in a standing position, with his or her back to a wall without a baseboard, with the body raised to its full height and the arms extended alongside the body. As this method was impossible for wheelchair users, the nutritional status of such individuals was estimated by means of the method of Chumlea et al. ${ }^{14}$ For the classification of nutritional classification according to body mass index (BMI), the specific cut-off points for elderly individuals recommended by Lipschitz ${ }^{15}$ were used.

The diagnosis of chronic constipation was defined according to the Rome III definition, ${ }^{16}$ which is based on the following specific criteria: straining during defecation; hard or lumpy stools; sensation of anorectal obstruction or blockage, manual maneuvers to facilitate defecation and fewer than three defecations per week. The presence of two or more criteria in at least $25 \%$ of defecations for a minimum of three months in a period of six months characterized the presence of constipation. ${ }^{16}$

In terms of statistical analysis, the quantitative variables were expressed as mean and standard deviation or median and interquartile range in conjunction with the range of variation. The qualitative variables were described by absolute and relative frequencies. For statistical analysis, the quantitative variables were expressed as mean and standard deviation or median and interquartile range in conjunction with the range of variation. The qualitative variables were described in absolute and relative frequencies. The Student's t-test was applied to compare means between the groups. In case of asymmetry, the Mann-Whitney test was used. To assess the association between qualitative variables, the chi-squared test or Fisher exact tests were applied.

A $5 \%(p \leq 0.05)$ level of significance was adopted and statistical analysis was performed with the SPSS version 18.0 software program.

\section{RESULTS}

Of the 87 elderly persons who made up the sample, the great majority were female $(80.5 \%)$ and the mean age was $79.4( \pm 9.6)$, with the majority $(52.9 \%)$ aged 80 or older. In relation to physical activity, 37 (42.5\%), elderly individuals performed light activity. The use of medications was identified in $100 \%$ of participants, and of these, 85 (97.7\%) of elderly persons used one or more drugs with side effects that may be constipating.

In terms of a family history of constipation, $58(66.7 \%)$ of individuals were able to say if their father, mother or both suffered from constipation, with $31(35.7 \%)$ having a history of the disease and $27(31.0 \%)$ having no history of the condition. Data regarding the general characteristics of the sample is described in table 1. 
Table 1. General characterization of the sample ( $\mathrm{n}=87$ ). Vale do Taquari-RS, 2013.

\section{Variables}

\section{Gender}

Female

Male

Age (years) - mean $( \pm)$ [min-max]

Age distribution
60-69 years
$16(18.4)$
70-79 years
$25(28.7)$
$\geq 80$ years
$46(52.9)$

Physical Activity

Yes*

No

Parents constipated

Don't remember

Mother or father (both with history)

Mother or father(both without history)
$27(31.0)$

min= minimum value $\max =$ maximum value $; *$ all considered as performing a light level of activity.

The data described in table 2 shows that the median average water intake was $700 \mathrm{~mL}$, with only $25.2 \%$ consuming $1500-2000 \mathrm{ml}$ per day, which is the recommended level for this population group. Mean fiber intake was $22.6( \pm 3.2) \mathrm{g} /$ day, which is also below the recommended level.
In terms of nutritional status, the mean BMI found was $25.4( \pm 4.4) \mathrm{Kg} / \mathrm{m}^{2}$, with the majority of elderly persons $(56.3 \%$ ) presenting a diagnosis of eutrophy. 
Table 2. Characterization of food intake and nutritional state ( $\mathrm{n}=87)$. Vale do Taquari-RS, 2013.

\begin{tabular}{lc}
\hline \multicolumn{1}{c}{ Variables } & $\mathrm{n}(\%)$ \\
Food consumption & $700(500-1500)[0-2500]$ \\
Water intake $(\mathrm{mL} /$ day $)-$ md $(\mathrm{P} 25-\mathrm{P} 75)[$ min-max $]$ & $17(19.5)$ \\
Classification of water intake & $33(37.9)$ \\
$<500 \mathrm{~mL}$ & $15(17.2)$ \\
$500-999 \mathrm{~mL}$ & $21(24.1)$ \\
$1000-1499 \mathrm{~mL}$ & $1(1.1)$ \\
$1500-2000 \mathrm{~mL}$ & $22.6( \pm 3.2)[13.3-27.7]$ \\
$>2000 \mathrm{~mL}$ & $25.4( \pm 4.4)[14.7-34.3]$ \\
Fiber consumption $(\mathrm{g} /$ day $)-$ mean $( \pm)[\mathrm{min}-\mathrm{max}]$ & \\
\hline Nutritional state & $18(20.7)$ \\
IMC (kg/m $\left.{ }^{2}\right)-$ mean $( \pm)[$ min-max $]$ & $49(56.3)$ \\
BMI classification & $20(23.0)$ \\
Low weight & \\
Eutrophy & \\
Overweight &
\end{tabular}

$\min =$ minimum value $\max =$ maximum value; $m d=$ median $; \mathrm{P} 25=$ percentile $25 ; \mathrm{P} 75=$ percentile 75 .

In table 3 , it can be seen that the prevalence of intestinal constipation was $42.5 \%$, being most frequent among women $(89.2 \%)$, aged 80 or more (67.6\%), who did not perform any kind of physical activity $(56.8 \%)$ and had a water and fiber intake below the recommended level.

In terms of the association between constipation and nutritional status, the highest prevalence of the condition was found in those classified as having normal weight. In addition, although not statistically significant, it is noteworthy that the prevalence of constipation was higher among elderly individuals with a parent with a history of the condition $(p=0.076)$.

When the relationship betweens the variables and constipation were analyzed, a statistically significant association was found between the condition and age $(p=0.049)$ and the consumption of fibers $(p=0.019)$. 
Table 3. Association of variables with constipation ( $\mathrm{n}=87)$. Vale do Taquari-RS, 2013.

Variables

Gender

Female

Male

Age (years) - mean $( \pm)$

Age range

60-69 years

70-79 years

$\geq 80$ years

Physical activity

Yes

No

Parents constipated

Don't remember

Mother or father(both with history)

Mother or father(both without history)

Water intake (mL/day) - md (P25-P75)

Classification of water intake

$<500 \mathrm{~mL}$

$500-999 \mathrm{~mL}$

1000-1499 mL

$\geq 1500 \mathrm{~mL}$

Fiber intake (g/day) - mean $( \pm)$

Classification of BMI

Low weight

Eutrophy

Over weight
Constipated $(n=37) \quad$ Not constipated $(n=50)$

$$
\text { n }(\%)
$$

n $(\%)$

$\mathrm{p}$

0.135

$33(89.2)$

$37(74.0)$

$4(10.8)$

$13(26.0)$

$81.8( \pm 8.6)$

$77.7( \pm 9.9)$

0.049

0.056

$4(10.8)$

$12(24.0)$

8 (21.6)

$17(34.0)$

$25(67.6)$

$21(42.0)$

1.000

$16(43.2)$

$21(42.0)$

$21(56.8)$

$29(58.0)$

0.076

$11(29.7) \quad 18(36.0)$

18 (48.6) $13(26.0)$

$8(21.6) \quad 19(38.0)$

$500(500-1000) \quad 775(500-1500) \quad 0.217$

0.347

$\begin{array}{lr}7(18.9) & 10(20.0) \\ 17(45.9) & 16(32.0) \\ 7(18.9) & 8(16.0) \\ 6(16.2) & 16(32.0)\end{array}$

$21.6( \pm 3.7)$

$23.3( \pm 2.7)$

0.019

0.736
7 (18.9)
$11(22.0)$
$20(54.1)$
$29(58.0)$
$10(27.0)$
$10(20.0)$

P25 = percentile $25 ; \mathrm{P} 75=$ percentile 75 . 


\section{DISCUSSION}

The prevalence of intestinal constipation found in the present study was $42.5 \%$. Studies performed in other populations obtained lower prevalences, varying from 22.5 to $40 \% .{ }^{17-19}$ Among other factors, this variation may be justified by the use of different diagnostic criteria, populations from different socio-cultural contexts, and also the broad age range evaluated. ${ }^{19}$ Nesello et al. ${ }^{20}$ evaluated elderly individuals frequenting a Day Center, where cultural, physical and recreational activities take place, and found a prevalence of constipation of $28.8 \%$. It appears, therefore, that constipation is a condition that affects institutionalized elderly persons more frequently, supporting other authors who have reported that this prevalence can reach $50 \% .^{11,21}$

Another factor that may contribute to the onset of constipation is old age. ${ }^{22}$ The findings of the present study found that the highest prevalence was among those aged 80 years or older. Other studies support these findings, showing an upward trend in the prevalence of constipation with advancing age. ${ }^{7,19}$ The high prevalence of constipation found among females is another finding that deserves attention. Factors such as differences in intestinal motility and visceral perception between the genders are associated with gastrointestinal diseases such as constipation. ${ }^{23}$ As in the present study, Collette et al. ${ }^{24}$ found a higher prevalence of the condition among women.

Physical inactivity, eating habits, water intake and polypharmacy are other factors that can be considered aggregators of constipation. Of the total sample of this study, the majority of respondents were considered to be sedentary. Corroborating these findings, a study conducted in three longterm care facilities for the elderly located in the municipality of Rio Claro, in the state of São Paulo, found that the level of physical activity was as low for men as for women. ${ }^{25}$ This fact can be explained both by age and functional disability. ${ }^{5}$ While in this study the high prevalence of physical inactivity was not significantly related to constipation ( $p=1.000)$, and another study ${ }^{21}$ reported the same findings, regular physical activity should be performed and is recommended by the World Gastroenterology Organization ${ }^{26}$ as a way of managing intestinal constipation.

In terms of dietary aspects, both the consumption of fiber and water intake proved to be insufficient among the population studied. In old age, the necessary water intake is at least two liters a day, which is an important element in bowel function, keeping the mouth moist and the body hydrated. ${ }^{27}$ Low water consumption by the elderly can also more easily cause dryness of the stool, which may become petrified and very large, making defecation difficult. A study ${ }^{21}$ of elderly people where constipation was evaluated also found that their water intake was below the recommended level, with similar results to this study. Markland et al., ${ }^{28}$ in a study based on the analysis of data from the National Health and Nutrition Examination Surveys (NHANES), found that the low consumption of water appeared as a predictive factor for constipation in men and women. Physiological hypertrophy in the hypothalamus, which controls thirst, is one factor which may explain the decrease in water consumption in this population. ${ }^{3}$

In terms of the consumption of fibers, the mean amounts for both constipated and non-constipated individuals were below recommended levels. Corroborating these findings, Salcedo \& Kitahara ${ }^{29}$ also identified an insufficient consumption of fibers when evaluating 48 institutionalized elderly persons in São Paulo, with a mean intake of 12.45 $\mathrm{g} /$ day. In the present study, the consumption of fibers was the variable that had the most significant relationship with constipation $(p=0.019)$, showing that, despite all the elderly individuals evaluated having a mean intake below the recommended levels, among those considered constipated the mean fiber intake was even lower compared than in non-constipated individuals.

These findings show the importance of a diet with a fiber intake of at least $25 \mathrm{~g} / \mathrm{day},{ }^{30}$ in order to avoid the appearance or worsening of symptoms related to constipation 
When evaluating the nutritional state of the elderly persons, the mean BMI, 25.4kg/ $\mathrm{m}^{2}$, corroborated the findings of other studies that performed the same evaluation among institutionalized elderly individuals. ${ }^{31,32}$ As in the present study, Collete et al. ${ }^{24}$ failed to find a statistically significant association between BMI and gastrointestinal symptoms.

Among the limitations of the present study, the fact that the questionnaire used for the collection of data, despite being structured, has not been validated. Another important point is the crosssectional character of the study, which does not allow cause and effect type associations to be performed. Another possible limitation is the possibility of memory bias in relation to the data provided, given that the information was largely supplied by the elderly persons themselves.

\section{REFERENCES}

1. De Oliveira SCM, Pinto-Neto AM, Góes JRN, Conde DM, Santos-Sá D, Costa-Paiva L. Prevalence and factors associated with intestinal constipation in postmenopausal women. Arq Gastroenterol 2005;42(1):24-3

2. Instituto Brasileiro de Geografia e Estatística. Projeção da população do Brasil: população brasileira envelhece em ritmo acelerado. IBGE. 27 Nov 2008. Comunicação Social.

3. Bosshard W, Dreher R, Schnegg JF, Büla CJ. The treatment of chronic constipation in elderly people: an update. Drugs Aging 2004;21(14):911-30.

4. Netto MP. Tratado de gerontologia. 2 ed. São Paulo: Atheneu; 2007. Ciência do envelhecimento: abrangência e termos básicos e objetivos; p. 29-38.

5. Menezes TN, Marucci MFN. Antropometria de idosos residentes em instituição geriátricas. Fortaleza. Rev Saúde Pública 2005;39(2):169-75.

6. Alame AM, Bahna H. Evaluation of constipation. Clin Colon Rectal Surg 2012;25(1):5-11.

7. Jaime RP, Campos RC, Santos TST, Marques MS. Prevalência e fatores de risco da constipação intestinal em universitários de uma instituição particular de Goiânia, GO. Rev Inst Ciênc Saúde 2009;27(4):378-83.

\section{CONCLUSION}

The prevalence of constipation in the studied population group was $42.5 \%$, which is higher than that found in studies of non-institutionalized elderly persons and confirms what other authors have reported: namely, that this condition is very prevalent among the elderly. Constipation proved to be a multifactorial digestive complaint, with advanced age and low consumption of fiber significantly associated with the condition. Various studies have addressed the relationship between constipation and hereditary factors, and while the present study did not identify a significant correlation between the two, it was found that there was a higher prevalence of constipation among those who reported having a constipated father, mother or both.

8. Gavanski OS, Baratto I, Gatti RR. Avaliação do hábito intestinal e ingestão de fibras alimentares em uma população de idosos. Rev Bras Obes Nutr Emagrecimento 2015;9(49):3-11.

9. Peppas G, Alexiou VG, Mourtzoukou E, Falagas ME. Epidemiology of constipation in Europe and Oceania: a systematic review. BMC Gastroenterology. 2008;8:1-7.

10. Lembo MDA, Camilleri MD. Chronic Constipation. N Engl J Med 2003; 349(14):1360-8.

11. Organização Mundial de Gastroenterologia. Constipação: uma perspectiva mundial. Organização Mundial de Gastroenterologia; 2010.

12. Pleis JR, Lethbridge M. Summary health statistics for U.S. adults: national health interview survey, 2005. Washington: National Center for Health Statistics; 2006. (Vital and Health Statistics), (Séries 10, n. 23).

13. Institute of Medicine, Food and Nutrition Board. Dietary reference intakes: energy, carbohydrate, fiber, fat, fatty acids, cholesterol, protein, and amino acids. Washington: National Academy Press; 2002.

14. Chumlea WC, Roche AF, Steinbaugh ML. Estimating stature from knee height for persons 60 to 90 years of age. J Am Geriatr Soc 1985;33(2):116-20. 
15. Lipschitz DA. Screening for nutritional status in the elderly. Prim Care 1994; 21(1):55-67.

16. Tomiko Born, organizadora. Cuidar melhor e evitar a violência: manual do cuidador da pessoa idosa. Brasília, DF: Secretaria Especial dos Direitos Humanos, Subsecretaria de Promoção e Defesa dos Direitos Humanos; 2008.

17. Beckenkamp J, Santos JS. Efeito da linhaça sobre a constipação intestinal em idosos residentes em instituições geriátricas. Rev Bras Ciênc Envelhec Humano 2011;8(2):179-87.

18. Machado WM, Capelari SM. Avaliação da eficácia e do grau de adesão ao uso prolongado de fibra dietética no tratamento da constipação intestinal funcional. Rev Nutr 2010;23(2):231-8.

19. Braz CRS, Lessa NMV. Fatores de risco e prevalência de constipação intestinal em graduandos do curso de nutrição de um centro universitário de Minas Gerais. Rev Digit Nutr 2011;5(8):740-54.

20. Nesselo LAN, Tonelli FO, Beltrame TB. Constipação intestinal em idosos frequentadores de um Centro de Convivência no município de Itajaí-SC. Ceres Nutr Saúde 2011;6(3):151-62.

21. Cota RP, Miranda LS. Associação entre constipação intestinal e estilo de vida em estudantes universitários. Rev Bras Nutr Clín 2006;21(4):296-301.

22. Oliveira JN, Tahan S, Goshima S, Fagundes-Neto, De Morais MB. Prevalência de constipação em adolescentes matriculados em escolas de São José dos Campos, SP, e em seus pais. Arq Gastroenterol 2006;43(1):50-4.

23. Lin C, Toner BB, Shin F, Guthrie E, Locke GR, Norton NJ, et al. Gender, age, society, culture, and the patient's perspective in the functional gastrointestinal disorders. Gastroenterology 2006;130(5):1435-46.
24. Collete VL, Araújo CL, Madruga SW. Prevalência e fatores associados a constipação intestinal: um estudo de base populacional em Pelotas, Rio Grande do Sul, Brasil, 2007. Cad Saúde Pública 2010;26(7):1391-1402.

25. Vargas-García EJ, Vargas-Salado F. Food intake, nutritional status and physical activity between elderly with and without chronic constipation: a comparative study. Cir \& Cir 2013;81(3):214-20.

26. Buchman AS, Boyle PA, Wilson RS, Bienias JL. Physical activity and motor decline in older persons. Muscle Nerve 2007;35(3):354-62

27. Brasil. Ministério da Saúde, Secretaria de Atenção à Saúde, Departamento de Atenção Básica. Alimentação saudável para a pessoa idosa: um manual para profissionais de saúde.Brasília, DF: Ministério da Saúde; 2009.

28. Markland AD, Plalsson O, Goode PS, Burgio KL, Busby-whitehead J, Whitehead WE. Association of low dietary intake of fiber and liquids with constipation: evidence from the National Health and Nutrition Examination Survey. Am J Gastroenterol 2013;108(5):796-803.

29. Salcedo RL, Kitahara SE. Avaliação do consumo semanal de fibras alimentares por idosos residentes em um abrigo. Conscientiae Saúde 2004; 3:59-64.

30. Brasil. Ministério da Saúde, Secretaria de Atenção à Saúde. Guia alimentar para a população brasileira : promovendo a alimentação saudável. Brasília, DF: Ministério da Saúde; 2008.

31. Trisóglio C, Marchi CMG, Torres US, Netinho JG. Prevalência de constipação intestinal entre estudantes de medicina de uma instituição no Noroeste Paulista. Rev Bras Coloproctol 2010;30(2):203-9.

32. Rauen MS, Moreira EAM, Calvo MCM, Lobo AS. Avaliação do estado nutricional de idosos institucionalizados. Rev Nutr 2008;21(3):303-10. 